\title{
A Study on Consumer Purchasing Behavior towards Herbal Products using Theory of Planned Behavior (TPB)
}

\author{
T. Nivetha*, K. Uma and P. Flowrine Olive \\ Department of Agricultural and Rural Management, Tamil Nadu Agricultural University, \\ Coimbatore - 641003, India \\ *Corresponding author
}

A B S T R A C T

\begin{tabular}{l} 
K e y w o r d s \\
$\begin{array}{l}\text { Consumer attitude, } \\
\text { Herbal products, } \\
\text { Theory of planned } \\
\text { behavior, Partial } \\
\text { least square method }\end{array}$ \\
\hline Article Info \\
$\begin{array}{l}\text { Accepted: } \\
\text { 24 July 2020 } \\
\text { Available Online: } \\
\text { 10 August } 2020\end{array}$ \\
\hline
\end{tabular}

Keywords

Consumer attitude, Herbal products, Theory of planned behavior, Partial Article Info

Accepted:

24 July 2020 10 August 2020

\section{Introduction}

Personal care products are defined as a wide variety of items that are commonly found in the health and beauty sections of drug and department stores such as skin moisturizers, perfumes, makeups, shampoos, toothpaste, mouthwashes, deodorants and others (FDA, 2016). Some of the products contain hazardous and poisonous ingredients such as mercury, hydroquinone and dexamethasone. Those substances may cause adverse effects on an individual's health such as irregular heartbeat, hypertension, cataract, kidney failure, high blood glucose level and Cushing syndrome which can lead to morbidity (Ministry of Health, 2015). Consumers are easily influenced by testimonials given by sellers and they easily fall prey into false promise of immediate results from these products (Yunus Mohamad et al., 2018). Consumer decision making are known to be greatly influenced by the economic situation, personal preferences and group influences. The difficulty of consumer decision making is influenced not only by the element of the task 
but also by how the information is provided in the environment (Bettman et al., 1991).

The objective of this study is to find out the factors responsible for influencing consumer attitude in purchasing herbal personal care products based on the theory of planned behavior (TPB) by Ajzen (1985). Specifically, this study considers consumer knowledge and appearance consciousness as an antecedent of attitude.

\section{Theoretical framework}

The theory of planned behavior (Ajzen, 1991) is the perfect version of theory of reasoned action (TRA) by adding perceived behavioral control variable, intended to make the consumers always referring to the presence of limited resource in behaving. The theory states that intention toward attitude, subject norms, and perceived behavior control, together shape an individual's behavior intentions and behaviors. Attitude refers to "the degree of a person's favourable or unfavourable evaluation or appraisal of the behavior in question" (Fishbein and Ajzen, 1975). Subjective norm refers to "the perceived social pressure to perform or not to perform the behavior" (Ajzen, 1991). Perceived Behavior Control refers to the "people's perception of ease or difficulty in performing the behavior of interest" (Ajzen, 1991, 2002). Past study revealed that attitude (Kim and Chung, 2011), subjective norms (Kim and Chung, 2011; Sumaedi et al., 2015) and perceived behavior control (Sumaedi et al., 2015) influenced consumer decision making.

People who have a positive attitude towards personal care products may influence their buying decision (Yunus Mohamad et al., 2018). In contrary to the above, a person's positive attitude on buying personal care products may not always lead to the intention of purchasing the products (Kim and Chung, 2011). Thus, attitude may or may not influence the consumer decision making on purchasing herbal personal care products. Sumaedi et al., (2015) stated that a person should engage in behavior even though the person does not have a positive feeling towards the products or its consequences but because of the influences, the person could be motivated enough to follow the referents. Subjective norm is the major driver of human behavior and very crucial in consumer decision making. Consumers always consider the expectations and behavior of others when they are deciding what is appropriate for them and thus subjective norm influenced their preferences and behavior (Yunus Mohamad, et al., 2018).

Perceived behavior control (PBC) is defined as a person's belief as how easy or difficult performance of the behavior is likely to be (Ajzen and Madden, 1986). According to Sumaedi et al., (2015), PBC shows the degree of what a person feels on his or her ability to overcome constraints to perform the behavior. It tries to measure the confidence toward the probability, feasibility, or likelihood of executing given behavior. All three factors contribute to make purchase intention of consumer which in result it produces the positive or negative behavior towards the herbal health care products.

Ajzen is supportive of modifications or additions, stating in 1991 that, "The theory of planned behavior is, in principle, open to the inclusion of additional predictors if it can be shown that they capture a significant proportion of the variance in intention or behavior after the theory's current variables have been taken into account".

The additional constructs such as consumer knowledge and appearance consciousness which influences the attitude when purchasing 
herbal health care products. Brucks (1985) described three kinds of consumer product class knowledge used in consumer behavior research namely: subjective knowledge, objective knowledge and prior experience. Consumption of personal care products is a purchasing behavior that satisfies one's needs for beauty and care of one's general appearance (Todd, 2004). Some people who strongly desire to maintain a youthful look and improve their appearances have been looking for chemical-free personal care products (Tirone, 2007). Based on the above information, the following hypothesis were framed.

H1: Appearance consciousness will positively influence attitude toward buying herbal personal care products.

H2: Consumer Knowledge will positively influence attitude toward buying herbal personal care products.

H3: Attitude will have a positive influence on their intentions to buy herbal personal care products.

H4: Subjective Norm will positively influence on their intention toward buying herbal personal care products.

H5: Perceived Behavioral Control will positively influence on their intention toward buying herbal personal care products.

\section{Materials and Methods}

The study was conducted using survey method among 120 respondents in Coimbatore. Coimbatore is more diverse and cosmopolitan than any other cities in Tamil Nadu. Respondents were selected using purposive sampling technique. Based on that, the survey was conducted at herbal stores in all zones of Coimbatore (West-Vadavalli, East-Ganapthy, South-Ukkadam, North-
Kavundampalayam, Central -R.S puram) using structured questionnaire. Partial Least Square method was the method used to analyze the sample respondents. The conceptual framework was framed as represented in fig. 1. Consumer knowledge (CK) 3 items were adapted from Schaefer (1997); Consumer attitude (CA) 3 items, Subjective norms (SN) 4 items, Perceived behavioral control (PBC) 3 items and consumption intentions were adapted from Tuan Tran (2016).Appearance consciousness (AC) 3 items were adapted from (Cash and Labarge, 1996) (Fenigstein et al., 1975). Item modification was performed to fit the context of the study and validated by experts in marketing. The measurement uses a five-point Likert scale, ranging from "strongly disagree" (1) to "strongly agree" (5). The conceptual framework was framed as below:

The proposed conceptual framework and hypotheses were analyzed using Partial Least Square (PLS) method in Smart PLS software. Bootstrapping method was used to determine the significance levels for loadings, weights and path coefficients. PLS Structural Equation Model is considered as a variance based technique to SEM. PLS can handle reflective and formative measurement models, as well as constructs with single and multi item measure, without identification problems. The main criteria to assess the structural model in PLS SEM are the significance of the path coefficient and $\mathrm{R}^{2}$ Values. The path coefficients refer to the hypothesized relationship between the constructs. The value of path coefficient range between -1 and +1 , where +1 indicate strong positive relationship. $\mathrm{P}$ value is used to assess the significance level. The coefficient of determination $\left(\mathrm{R}^{2}\right)$ value is the used to assess the structural model's predictive power. Value of $\mathrm{R}^{2}$ range between 0 and 1 , higher value represents higher accuracy level of prediction. 


\section{Results and Discussion}

\section{Descriptive analysis}

The demographic details of the sample respondents were shown below

The results showed that the samples of data were comprised of 44 male $(36.66 \%)$ and 76 female $(63.34 \%)$. It shows that females are more conscious about the nature of products they use and purchase. More than three- fourths of the respondents age was below 30 (63.34\%). Graduates (68\%) are more exposed to herbal health care products category. Respondents income per year between 150001-200000 shows high percentage (39.17\%) (Table 1).

\section{Partial least square method}

PLS SEM was used to validate the hypotheses and structural model, the results were presented in Figure 2 and Table 2.

Table.1 Demographic details of the sample respondents

\begin{tabular}{|c|c|c|c|}
\hline Characteristics & Category & $\begin{array}{c}\text { Number } \\
(\mathrm{n}=120)\end{array}$ & $\begin{array}{c}\text { Percentage } \\
\text { to total }\end{array}$ \\
\hline \multirow[t]{2}{*}{ Gender } & Male & 44 & 36.66 \\
\hline & Female & 76 & 63.34 \\
\hline \multirow[t]{4}{*}{ Age (in years) } & Upto30 & 76 & 63.34 \\
\hline & $31-40$ & 24 & 20.00 \\
\hline & $41-50$ & 11 & 9.16 \\
\hline & Above 50 & 9 & 7.50 \\
\hline \multirow[t]{4}{*}{ Education } & Illiterate & 6 & 5.00 \\
\hline & Primary education & 10 & 8.34 \\
\hline & Secondary education & 36 & 30.0 \\
\hline & Graduate & 68 & 56.66 \\
\hline \multirow[t]{3}{*}{ Occupation } & Business & 55 & 45.84 \\
\hline & Employee & 43 & 35.84 \\
\hline & Homemaker & 22 & 18.32 \\
\hline \multirow{5}{*}{$\begin{array}{l}\text { Annual income } \\
\text { in INR. }\end{array}$} & Upto 50,000 & 11 & 9.16 \\
\hline & $50000-1,00000$ & 24 & 20.00 \\
\hline & $1,00,000-1,50,000$ & 29 & 24.17 \\
\hline & $1,50,001-2,00,000$ & 47 & 39.17 \\
\hline & $>2,00,001$ & 9 & 7.50 \\
\hline
\end{tabular}


Table.2 Path coefficients and hypothesis testing

\begin{tabular}{|c|c|c|c|}
\hline Hypothesis & Path coefficient & $\mathbf{t}-$ values & Results \\
\hline H1: AP $\longrightarrow$ AT & 0.225 & $1.221^{\text {n.s }}$ & Not supported \\
\hline H2:CK $\longrightarrow$ AT & 0.445 & $4.011^{* * *}$ & Supported \\
\hline H3:PBC $\longrightarrow$ PI & 0.252 & $1.745^{*}$ & Supported \\
\hline H4:SN $\longrightarrow$ PI & 0.28 & $2.472^{* *}$ & Supported \\
\hline H5:AT $\longrightarrow$ PI & 0.324 & $2.566^{* *}$ & Supported \\
\hline
\end{tabular}

n.s. $=$ not significant. $\quad * \mathrm{p}<.1 ; * * \mathrm{p}<.05 ; * * * \mathrm{p}<.01$.

Fig.1 Conceptual framework

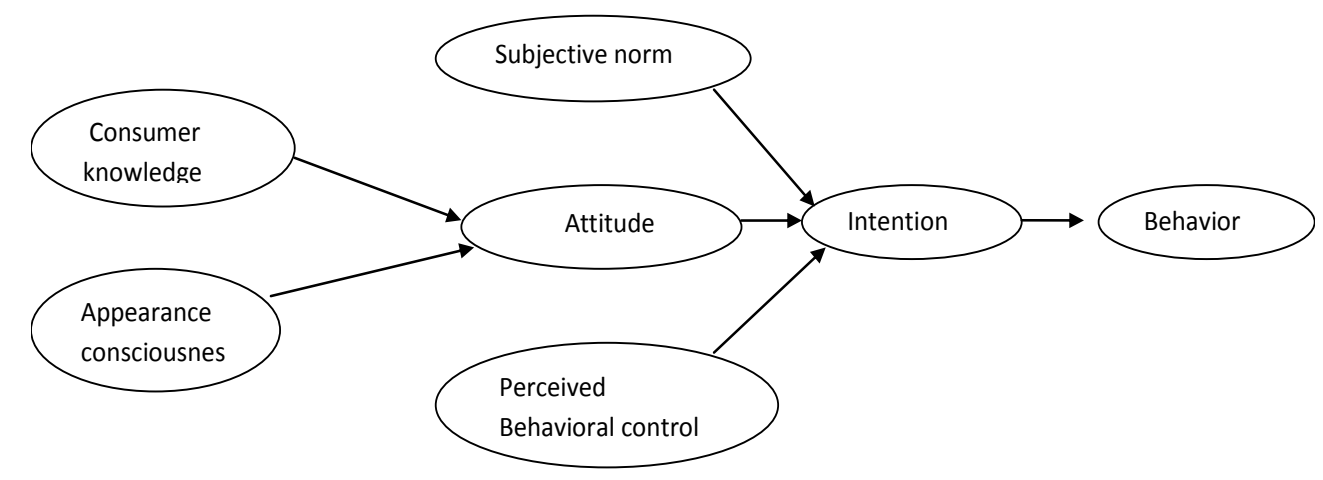

Fig. 2 The structural model

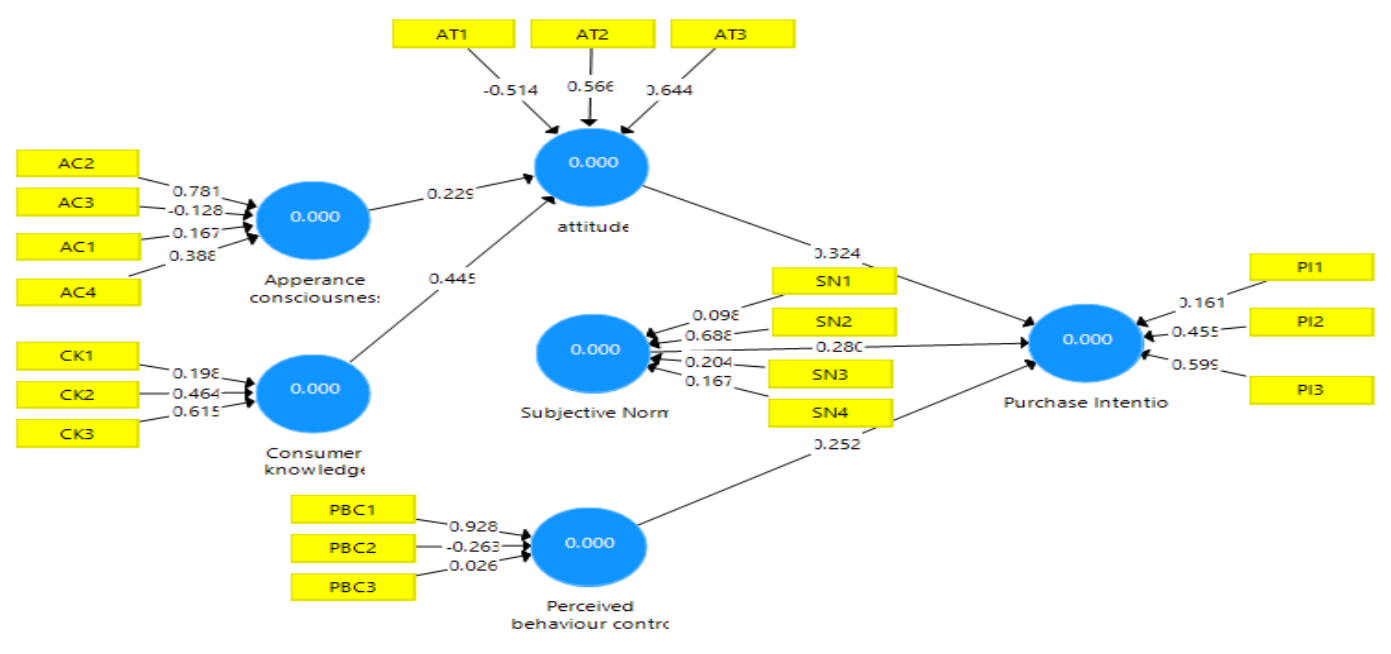


From figure 2, appearance consciousness is positively influencing attitude with path coefficient value of 0.225 and consumer knowledge also positively influencing the attitude with path coefficient value of 0.445 . It could be understood that consumer knowledge influencing the attitude than the appearance consciousness. In turn, attitude, subjective norms and perceived behavior control were having positive influence over the purchase intension with path coefficient of $0.324,0.28$ and 0.252 respectively. Hence, attitude is having more influence over the purchase intension than subjective norms or perceived behavior control.

From Table 2, the results shows that attitude (AT), subjective norms (SN), perceived behavioral control (PBC) positively influencing the consumer's purchase intention (PI) towards herbal personal care products. The additional construct, consumer knowledge (CK) positively influencing the attitude (AT) and appearance consciousness (AP) has no influence on consumer's attitude (AT) among the sample respondents. If consumers are more conscious about the appearance, they do not depend on herbal personal care products alone to get results. The $\mathrm{R}^{2}$ value for attitude is 0.54 , which means that $54 \%$ of the variables in attitude are good at explaining the purchase intention of the consumers. The $\mathrm{R}^{2}$ value for purchase intention is 0.655 that is $65.5 \%$ of dependent variables that is attitude, subjective norms and perceived behavior control are explaining the purchase intention of the consumers.

In conclusion, the demographic details shows that females respondents were high and majority respondents were in the age group of below 30 and are graduates. Majority high income peoples were using herbal health care products. PLS-SEM results explained that consumer knowledge has more influence on attitude towards herbal personal care products. Influence of attitude towards herbal products on purchase intention results also significant. Knowledge about the products influences the consumer attitude will lead to high level of consumer's purchase intention. Both subjective norms and perceived behavioral control factors have influence on consumer's purchase intention. Therefore, consumers are more likely to purchase herbal personal care products when they have positive attitude having more knowledge, subjective norms and perceived behavior control.

\section{Implication for marketers}

Marketers should concentrate on all income groups of people to acquire more market share. Effective advertisement will help the people to know about pros and cons of using herbal and non herbal products. Information about the products should be widespread in public through various ways of social media and through promotion campaign in order to increase the consumer knowledge about the herbal products.

\section{References}

Ajzen, I., and Fishbein, M. (1975). Attitudebehaviour relations: a theoretical analysis and review of empirical research. Psychological Bulletin, 84, 888-918

Ajzen, I. (1985). From intentions to actions: A theory of planned behavior. In J. Kuhl and J. Beckman (Eds.), Actioncontrol: From cognition to behavior (pp. 11- 39). Heidelberg, Germany: Springer.

Ajzen, I. (1991). The theory of planned behavior. Organizational Behaviour and Human Decision Processes, 50, 179211.

Brucks, M. (1985). The effects of product class knowledge on information search 
behavior. Journal of Consumer Research, 12(1), 1-16

FDA 2016 Food and Drug Administration (2016.). Consumers - Cosmetics Safety Q\&A: Personal Care Products.

Kim, H. and Chung, J. (2011), "Consumer purchase intention for organic personal care product", Journal of Consumer Marketing, 28(1), 40-47.

Ministry of Health, "Consumers cautioned against using cosmetic product containing scheduled poison," (2015), http://www.pharmacy.gov.my/v2/en/ne ws/09-jul-2014/consumers-cautionedagainst-usingcosmetic-productcontaining-scheduled-poison.html.

Payne, J., Bettman, J. R., and Johnson, E. J. (1991). Consumer decision making. Handbook of consumer behaviour, 5084.

Sumaedi, S., et al., (2015). Patient loyalty model: An extended theory of planned behavior perspective (a case study in Bogor, Indonesia). Leadership in Health Services, 28(3), 245-258

Todd A.M. (2004). The aesthetic turn in green marketing. Ethics and The environment, 9(2), 86-102. doi: 10.2979/ETE.2004.9.2.86

Tirone, A. (2007). Natural and body care drivers growth, inside cosmeceuticals, Retrieved from http://www.insidecosmeceuticals.com/a rticles/market- research.html

Yunus, Mohamad et al., (2018). "Generation Y Purchase Intention of Personal Care Products: The Influence of Attitude, Subjective Norms and Perceived Behavioural Control" Journal of International Business, Economics and Entrepreneurship (2018): pp. 30-36.

\section{How to cite this article:}

Nivetha, T., K. Uma and Flowrine Olive, P. 2020. A Study on Consumer Purchasing Behavior towards Herbal Products using Theory of Planned Behavior (TPB). Int.J.Curr.Microbiol.App.Sci. 9(08): 3290-3296. doi: https://doi.org/10.20546/ijcmas.2020.908.376 